\title{
Paideusis
}

\section{The Enlightened Eye: Qualitative Inquiry and the Enhancement of Educational Practice (Elliot W. Eisner)}

\section{Barrie R.C. Barrell}

Volume 8, Number 2, 1995

URI: https://id.erudit.org/iderudit/1073259ar

DOI: https://doi.org/10.7202/1073259ar

See table of contents

Publisher(s)

Canadian Philosophy of Education Society

ISSN

0838-4517 (print)

1916-0348 (digital)

Explore this journal

Cite this review

Barrell, B. (1995). Review of [The Enlightened Eye: Qualitative Inquiry and the Enhancement of Educational Practice (Elliot W. Eisner)]. Paideusis, 8(2), 47-50. https://doi.org/10.7202/1073259ar 
Elliot W. Eisner, The Enlightened Eye: Qualitative Inquiry and the Enhancement of Educational Practice. New York, NY: Macmillan Publishing Company; Toronto, ON: Collier Macmillan Canada, 1991.

This erudite work is informed by a profound knowledge of philosophic (K. Popper, R. Rorty, A. deTocqueville, S. Toulmin), artistic (J. Dewey, N. Goodman, S. Langer, H. Read), and critical (M. Apple, M. Polanyi, P. Hirst) sources. By using ideas anchored deep within the arts and humanities, Eisner constructs the foundation of educational criticism and "connoisseurship." His notion of connoisseurship is not elitist, but is seen as the art of studied appreciation. This appreciation is developed through field-based educational experiences where perceptivity is sharpened by articulate, observant writing. His text suggests more than a refinement of existing qualitative research methodologies. He offers a way of creating knowledge by avoiding a false dichotomy between quantitative and qualitative research; instead, he emphasises pluralities. Like van Manan and other qualitative researchers, he insists that it is the vibrancy of the written text that is key to qualitative inquiry.

Two-thirds into his text, Eisner turns attention to a qualitative written analysis of an American Educational Research Association video tape of a highschool history lesson. The subject is James Madison's Federalist Papers, specifically Paper 10; the teacher, Bill Bennett, U.S. Secretary of Education; the class, a mixed group of students from Banneker High, a public school near Washington, DC. "The event ... was meant to show a Washington bureaucrat getting in touch with the reality of schools and ... demonstrating how substantive teaching could be provided to America's youth"' (p. 129). Also present in the classroom are various journalists and television people ready to send reports and telecasts across the United States.

Quickly Eisner gets us into Bennett's lesson. Practising what he has preached, he takes us inside the classroom, rendering a scene that included the presence of the media. He draws us into the lesson and gives a feel for the issues at hand. A picture begins to emerge of a teacher working very familiar territory. Historical events are brought into the present by Bennett and woven into current themes of dissent or juxtaposed against tyranny. Student questions, though probably heard in various forms many times before, are treated with care and answered with respect by the Secretary. From Eisner's description, one feels the heat of the TV lights. The spotlight closes in on the Education Secretary trying to show how teaching can be done effectively. We see Bennett getting down to business, intently pacing the floor, sleeves rolled up. Students are made to feel that this is very serious material. Eisner's crisp descriptive prose clearly demonstrates his point that it is language that forms the foundation upon which qualitative inquiry is built. He not only tells us, but shows through vivid and precise language that this is a masterful lesson on the Federalist Papers.

Eisner's objective at this point in The Enlightened Eye is to present, examine, and compare various forms of educational criticism. We have been prepared carefully for this task. The preceding chapters have given the reader an overview of the aims and issues of qualitative inquiry and we have been shown the tools for this type of inquiry and "connoisseurship." They are shown to evolve out of a methodological pluralism. Qualitative inquiries need to be "field focused" (p. 32), use the "self as an instrument" of the inquiry (p. 33), 
account for what the research has given an account of (p. 35), use language expressively and insist that it speak with an authentic voice. Further, the inquirer must pay attention to the particulars of the study and sift out what is important, for the "expert knows what to neglect" (p. 38). Finally, the text needs to be made believable through the "coherence, insight, and instrumental utility" where the facts are not left to speak for themselves (p. 39).

Eisner's view of the Bennett lesson is an example of educational criticism. He is giving us a personal, insightful, and, at times, literary view of a teacher in full flight. He is a connoisseur of the situation. But is his description of Bennett valid? Is it useful? How do we test the veracity of these subjective renderings? How do we judge the reliability of his comments? As Eisner states, "one of the persistent sources of difficulty for those using qualitative methods of research and evaluation pertains to questions about the validity of the work" (p. 107). Unlike some social science writing, Eisner's does not avoid using metaphor and simile. He refuses to neutralise his voice. Rather, he crafts a text through epistemic seeing so that we can share what has been experienced. It is his prose that establishes his credibility; he knows classrooms well and has observed teachers closely. His writing blends a confluence of sources and themes. Pieces of evidence, captured in substantive language, nun tightly together to establish a coherence.

Eisner devotes several chapters to explaining why qualitative research is a valid form of inquiry and goes to great lengths to establish the validity of its findings and how that knowledge is mediated. This mediation uses presuppositions from the arts, the humanities, and the social sciences for rendering pictures of schools and classrooms. This is done to "broaden our views about what it means to know" and "to contribute to the improvement of education" (p. 2). Eisner does not want to see us abandon quantitative research, but to join Rorty, Toulmin, and Popper in recognising multiple ways of knowing (p. 4, 45).

However, Eisner's analysis of Bennett's lesson is flawed. Interestingly, he breaks one of his criteria for developing a text: "The most important test of any qualitative study is its usefulness" (p. 58). In questioning any quantitative research, we might examine the breadth of the gathered data, the researcher's sampling techniques, the construction of the instrument used, or the appropriateness of the conclusions drawn. We might go as far as to question a researcher's writing style, but only if the APA has been seriously offended.

In qualitative research, it is the written text that must carry the day; it is the clarity of the writing that makes things believable. Does Eisner's classroom description of the Secretary inform us in the same way as the works of Philip Jackson, Theodore Sizer, Erving Goffman, or Sara Lawrence Lightfoot? Yes, it does, if we want to know about how a Secretary of Education can handle a well-rehearsed topic in forty-five minutes. However, beyond that, it tells us very little about teaching in the public schools. Let us think about the real scene in that classroom. With the Secretary of Education coming to teach, how many students would have come to class that day without their homework done? Indeed, we are told that Bill Bennett is teaching Banneker High's "best and brightest" (p. 130), a selected bunch of kids all of whom we can assume are eager, excited, thrilled, well tutored, and willingly attentive to such a Washington personality. As a "teacher" (Bennett does not have the professional credential to be licensed as a teacher in any of the fifty states or the 
District of Columbia), he proceeds to deliver a lecture disguised as an exchange of ideas. Bennett could obviously anticipate any questions that would come his way from the assembled class. After all, this is the philosopher's home turf: "It is obvious that he has taught it before, and often .... He repeats passages verbatim from ... Federalist 10"' (p. 132). From Eisner's account and Roger Shuy's fifteen-page detailed analysis of the video tape that follows Eisner's own analysis, we learn Bennett's lesson is uninterrupted. No mention is made of collecting a late slip or a letter excusing a student's absence. No student asks to leave the room to get a drink or visit the bathroom. No interruptions come via the public address system or class door. On the humorous side, I imagine that a few secret service persons stationed outside in the hall have seriously cut into any thoughts a student might have about engaging in recalcitrant behaviour.

On a more serious note, some would broaden the analysis to question how a member of the Reagan administration dare give a lecture on Federalist 10 in light of the President's foreign and domestic policies and his treatment of the homeless and poor in the United States. Bennett, by using a recitation rather than a response model of instruction, is able to limit any discussions of racism-a topic of interest to the all black class. To the students' credit, they wished to expand the lesson to issues of racism. Shuy's analysis of their questions shows "evidences of student topics upon which responsive teaching might have been based ..." in the area of racism. Students "have no real voice unless the structure of the event permits them to have one" (p. 144). And in this case, after an authority in the form of the Secretary of Education has declared his position, the rules of engagement are stacked against any student participatory voice.

Why didn't Eisner chose a more neutral text upon which to focus enlightened eye? - and make no mistake, it is enlightened. Why couldn't he have looked at a real teacher teaching real students in a real classroom? What we are left with is a brilliant examination that uses all the techniques, dimensions, and important characteristics of educational criticism to render a picture of a counterfeit. The critic, in turning his energies to critiquing a public official playing at being a public school teacher, has a blind spot; he has confused the fake with the authentic. Ordinary classroom teachers are never served by such unfair comparisons.

There are important issues and situations that can be explored by the tools of educational criticism. But whether we use quantitative or qualitative methods of inquiry in education, we need to be sure that our findings will be worthwhile-that is, useful. Eisner would be the first to agree. In spite of this considerable error, the text is highly recommended for qualitative researchers and practitioners. Though "there is no codified body of procedures that will tell someone how to produce a perceptive, insightful, or illuminated study of the educational world" (p. 169), The Enlightened Eye equips those beginning their research with a set of lenses through which to interpret the prefigured or emergent focus of their work. The text will help in the selection of a research topic and its subsequent portrayal. Eisner has used his eclectic knowledge to refocus attention on substantial issues for the improvement of schools. The Enlightened Eye zooms in on many important subjects surrounding qualitative research and inquiry. Brave enough to admit his own past errors in "not leaving the site clean," Eisner tries to synthesize all the major issues surrounding school-based 
qualitative research. He addresses the question of whether qualitative research can be accumulative - that is, build upon other qualitative work. Issues of informed consent, confidentiality, real-life research mistakes, ethical tensions, research dilemmas, and privacy are all given thoughtful attention. He examines new ways of thinking about the nature of knowledge and how it can be represented and created. The Enlightened Eye is a very readable and enjoyable text; qualitative research is greatly advanced by its depth.

Reviewed by Barrie R.C. Barrell, Memorial University of Newfoundland 